American Journal of Applied Sciences 8 (4): 310-317, 2011

ISSN 1546-9239

(C) 2010 Science Publications

\title{
Synthesis, Characterization and Biological Activities of Organotin (IV) Methylcyclohexyldithiocarbamate Compounds
}

\author{
${ }^{1}$ Normah Awang, ${ }^{2}$ Ibrahim Baba, ${ }^{2}$ Bohari M. Yamin, \\ ${ }^{1}$ Mohd Sham Othman and ${ }^{3}$ Nurul Farahana Kamaludin \\ ${ }^{1}$ Environmental Health Programme, Faculty of Allied Health Sciences, \\ University Kebangsaan Malaysia, Jalan Raja Muda Abdul Aziz, 50300 Kuala Lumpur, Malaysia \\ ${ }^{2}$ Department of Chemistry, School of Chemical Science and Food Technology, \\ Faculty of Science and Technology, University Kebangsaan Malaysia, 43600 Bangi, Selangor, Malaysia \\ ${ }^{3}$ Department of Biomedical Science, Faculty of Allied Health Sciences, \\ University Kebangsaan Malaysia, Jalan Raja Muda Abdul Aziz, 50300 Kuala Lumpur, Malaysia
}

\begin{abstract}
Problem statement: The growing interest in the chemistry of sulphur donor ligands are due to their encouraging anticancer, antibacterial and antifungal activities as well as their widespread industrial application. Dithiocarbamates belong to this class and much attention has been paid to them. Approach: Novel organotin compounds with the molecular formula $\mathrm{R}_{\mathrm{m}} \mathrm{Sn}\left[\mathrm{S}_{2} \mathrm{CN}\left(\mathrm{CH}_{3}\right)\left(\mathrm{C}_{6} \mathrm{H}_{11}\right)\right]_{4-\mathrm{m}}$ (where $\mathrm{m}=2, \mathrm{R}=\mathrm{CH}_{3}, \mathrm{C}_{2} \mathrm{H}_{5} ; \mathrm{m}=3, \mathrm{R}=\mathrm{C}_{6} \mathrm{H}_{5}$ ) have been synthesized using in situ method. These compounds were characterized by elemental analysis, IR, ${ }^{1} \mathrm{H}$ and ${ }^{13} \mathrm{C}$ NMR spectroscopy. Results: Elemental analysis revealed that all compounds were of good purity. Infrared spectra of the compounds showed that the thioureide $v(\mathrm{C}-\mathrm{N})$ band was in the region $1450-1500 \mathrm{~cm}^{-1}$. The unsplitting band of $v(\mathrm{C}-\mathrm{S})$ in the region $974-979 \mathrm{~cm}^{-1}$ indicated the bidentate nature of the chelated dithiocarbamato legends. The ${ }^{13} \mathrm{C}$ NMR chemical shift of the carbon atom in the $\mathrm{N}-\mathrm{CS}_{2}$ group appeared in the range of 196.29-199.82 ppm. Single crystal analysis from one of these compounds showed that the chelating mode of the dithiocarbamate groups was isobidentate. These compounds have been screened for antibacterial activity against four bacteria; Staphylococcus aureus, Salmonella typhimurium, Pseudomonas aeruginosa and Bacillus subtilis. Only one of these compounds shows promising results against $S$. aureus and S. typhi. Cytotoxicity screening on human leukemic promyelocyte HL-60 cells found that two of these compounds were very active with $\mathrm{CD}_{50}$ values of 0.87 and $0.18 \mu \mathrm{g} \mathrm{mL}^{-1}$. Conclusion: The studied compounds were found to have the potential in biological activity especially in cytotoxicity where this possibly can be used for clinical trials after further research.
\end{abstract}

Key words: Salmonella typhimurium, infrared spectra, biological activities, staphylococcus aureus, antibacterial activity, synthesized compounds, disc diffusion, elemental analysis

\section{INTRODUCTION}

Organotin compounds have a wide range of applications and they are amongst the most widely used organometallic chemicals. The organotin (IV) compounds possess significant biological activities (Kang et al. 2009; Wu et al. 2009; Alama et al. 2009; Affan et al 2009). These compounds have been found as antitumor (Mohan et al., 1988; Ruan et al., 2011), antibacterial (Maiti et al., 1988; Gleeson et al. 2008), antifungal (Manav et al., 2000; Singh and Kaushik, 2008) and antiviral (Singh et al., 2000). These compounds have been widely used as agrochemicals and antifouling paints due to their low phototoxicity and favourable environmental degradation to non-toxic inorganic residues. Organotin(IV) compounds are extensively studied due to its coordination geometries as well as structural diversity (Amini et al. (2009).

The dithiocarbamates $\left(\mathrm{R}_{2} \mathrm{NCS}_{2}^{-}\right)$are the halfamides of dithiocarbonic acid. These are the sulphur analogs of carbamates $\left(\mathrm{R}_{2} \mathrm{NCO}_{2}{ }^{-}\right)$. The strong metal binding properties of dithiocarbamates are directly related to their possession of two donor sulphur atoms. Dithiocarbamates are the main group of fungicides used to control approximately 400 pathogens of more than crops and registered in all the EU member states and many other countries.

Corresponding Author: Normah Awang, Environmental Health Programme, Faculty of Allied Health Sciences, University Kebangsaan Malaysia, Jalan Raja Muda Abdul Aziz, 50300 Kuala Lumpur, Malaysia Tel: +60326878126 
In this study, we report on the synthesis, characterization, antibacterial and cytotoxicity activities of some new organotin (IV) compounds using Nmethylcyclohexylamine, which consist of dimethyltin (IV) dichloride, dibutyltin (IV) dichloride and triphenyltin (IV) chloride. The structure of dimethyltin (IV) methylcyclohexyldithiocarbamate (compound 1) also has been report in this study.

\section{MATERIALS AND METHODS}

Reagents: Dimethyltin(IV) dichloride, dibutyltin(IV) dichloride, N-methylcyclohexylamine and ethanol (95\%) were obtained from Fluka Chemical. Carbon disulphide and methanol (99.5\%) from Ajax Chemical Ltd. Chloroform was purchased from Merck. All the chemicals were used as supplied without purification.

Synthesis of dithiocarbamate complexes: Dimethyltin(IV), dibutyltin(IV) and triphenyltin(IV) methylcyclohexyldithiocarbamate compounds (compound 1-3) were synthesized by the method given by Thirumaran et al. (1998) with some modifications. To a stirred solution of N-methylcyclohexylamine (30 mmol) in $30 \mathrm{~mL}$ of ethanol was added carbon disulphide $(30 \mathrm{mmol})$ to obtain slightly yellow reaction mixture. The reaction mixture was then stirred for 1 hour at temperature below $4^{\circ} \mathrm{C}$. After that, a prescribed amounts of organotin(IV) chloride (dimethyltin(IV) dichloride, dibutyltin(IV) dichloride, triphenyltin(IV) chloride) was added. The solution was stirred vigorously at below of $15^{\circ} \mathrm{C}$ for $2 \mathrm{hrs}$. The white precipitate formed was filtered and washed with ethanol and later dried in vacuo over silica gel. All recrystallization of products were done from the mixture of chloroform and ethanol $(1: 3 \mathrm{v} / \mathrm{v})$.

Physical measurements: Melting points were determined in a capillary tube using electrothermal melting point apparatus model MP-D Mitamura Riken Kogyo (Japan). Elemental analysis was carried out on Fison EA $1108 \mathrm{CHN}$ analyzer. IR and far IR spectra were recorded on $\mathrm{KBr}$ and polyethylene discs, respectively, using a Perkin Elmer FTIR Model GX spectrometer in the frequency range $4000-500 \mathrm{~cm}^{-1}$ and $500-200 \mathrm{~cm}^{-1} .{ }^{1} \mathrm{H}$ and ${ }^{13} \mathrm{C}$ NMR spectra were recorded using Joel JNM-LA 400 spectrometer.

X-ray crystallography: Room-temperature diffraction data were collected on a Bruker SMART APEX areadetector diffractometer (Mo $\mathrm{K} \alpha$ radiation, $\lambda=0.71073$ $\AA$ ) on a crystal with size of $0.27 \times 0.22 \times 0.16 \mathrm{~mm}$ over the range $1.76<\theta<27.0$. The structure was solved and refined by using the SHELXS-97. The final $\mathrm{R}(\mathrm{I}>2 / \mathrm{s}(\mathrm{I})$ ) and $\mathrm{Rw}$ values were 0.07 and 0.1820 respectively. All non-hydrogen atoms were refined anisotropically. The perspective view of the molecule was obtained using SHELXTL. Selected bond distances and angles are listed in Table 6.
Cytotoxicity screening: The synthesized compounds (1-3) were screened for the preliminary in vitro anticancer activity against human leukemic promyelocyte HL-60 cell line by MTT (3-(4,5dimethylthiazo-2-yl)- 2,5-diphenyl-tetrazolium bromide) assay reported by Mosmann (1983). The human leukemic promyelocyte HL-60 cell line was obtained from the National Cancer Institute, Frederick, Maryland, USA. The cell was cultured in RPMI-1640 (Sigma) medium supplemented with $10 \%$ fetal calf serum (Flow Lab). Solutions of different concentrations were prepared from stock solutions $\left(10 \mathrm{mg} \mathrm{cM}^{-3}\right)$ by serial dilution in RPMI-1640 to give a volume of 100 $\mu \mathrm{L}$ in each well of a microtiter plate as described by Ali et al. (1999). Each well was filled with $100 \mu \mathrm{L}$ of cell suspension in a complete growth medium (CGM) at 1$2 \times 10^{5}$ cells $\mathrm{cm}^{-3}$. The $\mathrm{CD}_{50}$ value represents the concentration, which results in a $50 \%$ decrease in cell growth after $24 \mathrm{hrs}$ of incubation. Etoposide was used as control.

Disc diffusion antimicrobial assay: The bacterial species used in this study were Staphylococcus aureus, Salmonella typhimurium, Pseudomonas aeruginosa and Bacillus subtilis. In the screening of antibacterial activity, the disc diffusion method (Andrews, 2001) was employed. Sterile study discs (Whatman No. 1, 6 $\mathrm{mm}$ diameter) were loaded with $100 \mathrm{ml}$ of each of the stock solution $(10 \mathrm{mg} \mathrm{mL}$ ) to give a final concentration of $1 \mathrm{mg} / \mathrm{disc}$. An even spread of microorganism was prepared by transferring $50 \mathrm{ml}$ of microbial suspension to Mueller-Hinton agar plates for bacteria and SDA plates for yeast using sterile cotton buds. As for the dermatophytes, $100 \mathrm{ml}$ of the spore suspension was added to $20 \mathrm{ml}$ of molten PDA before they were poured out into the sterile plates. The discs were then positioned on the inoculated agar surface. Each compound solution was assayed in triplicate. Streptomycin $(10 \mathrm{mg} / \mathrm{disc})$ was used as standard antibiotic agent, whereas PBS was used as a negative control. The plates of all bacteria strains were then incubated at $37^{\circ} \mathrm{C}$ for $24 \mathrm{~h}$. On the other hand, the plates of dermatophytes were incubated at $27^{\circ} \mathrm{C}$ for duration between 48-72 h. The screening for antibacterial activity was done by measuring the diameter of a clear inhibition zone around the disc. The mean diameter of inhibition zone was measured to the nearest millimeter $(\mathrm{mM})$ based on three readings of the diameter zones of each target microorganism using the vernier caliper.

\section{RESULTS}

The direct reaction of N-methylcyclohexylamine with organotin (IV) chloride yields the organotin (IV) methylcyclohexyldithiocarbamate compounds in a good percentage. Elemental analysis and physical properties data for compound 1-3 are given in Table 1. The reaction schemes for the above preparation are given in Fig. 1. 
Am. J. Applied Sci., 8 (4): 310-317, 2011

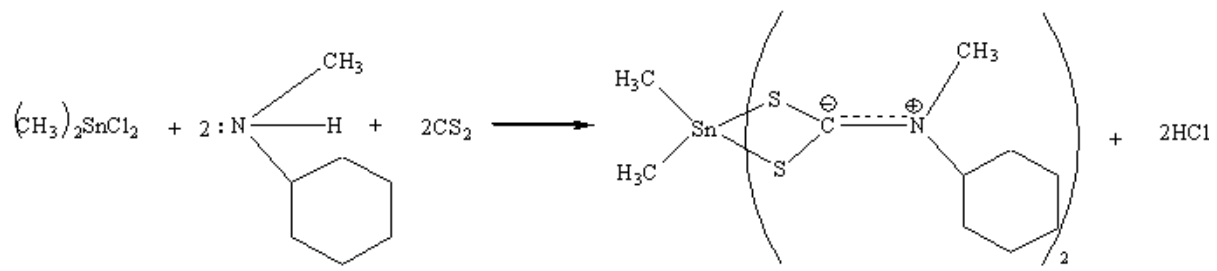

(a)

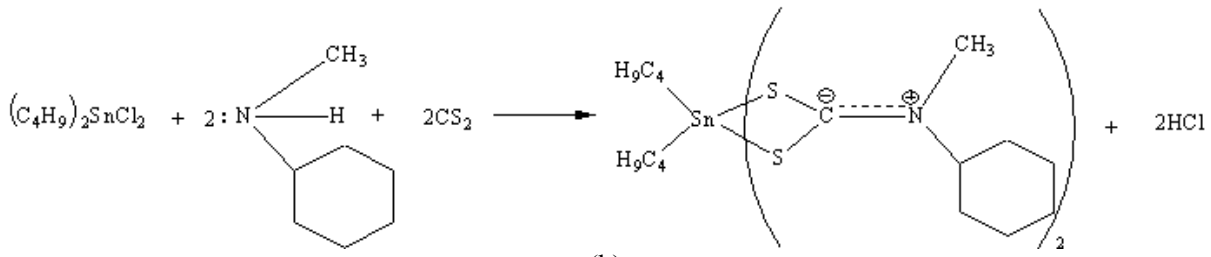

(b)

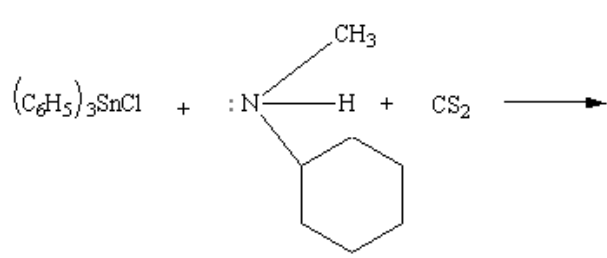<smiles></smiles>

(c)

Fig. 1: The Reactions between N-methyl-N-cyclohexylamine, Carbon Disulfide and Organotin(IV) Chloride

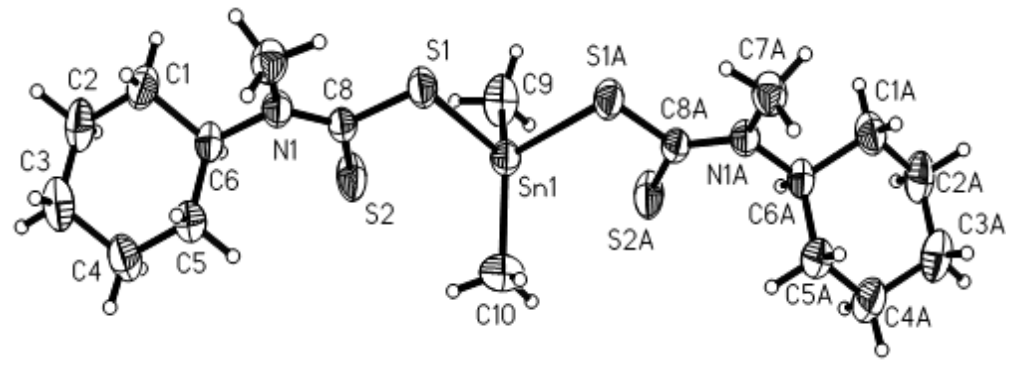

Fig. 2: ORTEP plot of compound 1 at he $50 \%$ probability level

Table 1: Physical and Elemental analysis data of organotin(IV) $N$-methyl- $N$-cyclohexyldithiocarbamate compounds

\begin{tabular}{|c|c|c|c|c|c|c|c|c|}
\hline \multirow[b]{2}{*}{ Molecular formula } & \multirow[b]{2}{*}{ Color } & \multirow[b]{2}{*}{ Yield (\%) } & \multirow[b]{2}{*}{$\begin{array}{l}\text { Melting } \\
\text { point }\left({ }^{\circ} \mathrm{C}\right)\end{array}$} & \multicolumn{5}{|c|}{ Found (Calculated) (\%) } \\
\hline & & & & $\mathrm{C}$ & $\mathrm{H}$ & $\mathrm{N}$ & $\mathrm{S}$ & $\mathrm{Sn}$ \\
\hline$\left(\mathrm{CH}_{3}\right)_{2} \mathrm{Sn}\left[\mathrm{S}_{2} \mathrm{CN}\left(\mathrm{CH}_{3}\right)\right.$ & Colorless & 89 & 147.9- & 40.66 & 6.46 & 5.30 & 26.43 & 23.12 \\
\hline$\left.\left(\mathrm{C}_{6} \mathrm{H}_{11}\right)\right]_{2}($ compound 1$)$ & & & 148.8 & 41.14 & 6.48 & 5.33 & 24.38 & 22.67 \\
\hline$\left(\mathrm{C}_{4} \mathrm{H}_{9}\right)_{2} \mathrm{Sn}\left[\mathrm{S}_{2} \mathrm{CN}\left(\mathrm{CH}_{3}\right)\right.$ & Colorless & 83 & $122.6-$ & 47.15 & 8.08 & 4.62 & 22.72 & 17.92 \\
\hline$\left.\left(\mathrm{C}_{6} \mathrm{H}_{11}\right)\right]_{2}$ (compound 2$)$ & & & 124.0 & 47.29 & 7.55 & 4.60 & 21.02 & 19.54 \\
\hline$\left(\mathrm{C}_{6} \mathrm{H}_{5}\right) \mathrm{Sn}\left[\mathrm{S}_{2} \mathrm{CN}\left(\mathrm{CH}_{3}\right)\right.$ & Colorless & 76 & $136.8-$ & 57.71 & 4.98 & 2.57 & 11.26 & 23.05 \\
\hline$\left.\left(\mathrm{C}_{6} \mathrm{H}_{11}\right)\right]$ (compound 3) & & & 138.2 & 57.99 & 5.39 & 2.60 & 11.90 & 22.12 \\
\hline
\end{tabular}

Table 2: The important infrared absorption bands $\left(\mathrm{cm}^{-1}\right)$

\begin{tabular}{llllll}
\hline Compounds & $v(\mathrm{C}-\mathrm{H})$ & $v(\mathrm{C}=\mathrm{N})$ & $v(\mathrm{~N}-\mathrm{C})$ & $v(\mathrm{C}=-\mathrm{s})$ & $\mathrm{v}(\mathrm{Sn}-\mathrm{C})$ \\
\hline 1 & 2927 & 1475 & 1147 & 974 & 354 \\
2 & 2925 & 1459 & 1147 & 975 & 532 \\
3 & 2938 & 1478 & 1148 & 979 & 359 \\
\hline
\end{tabular}


Am. J. Applied Sci., 8 (4): 310-317, 2011

Table 3: ${ }^{1} \mathrm{H}$ NMR spectra data of compound $1-3(\delta, \mathrm{ppm})$

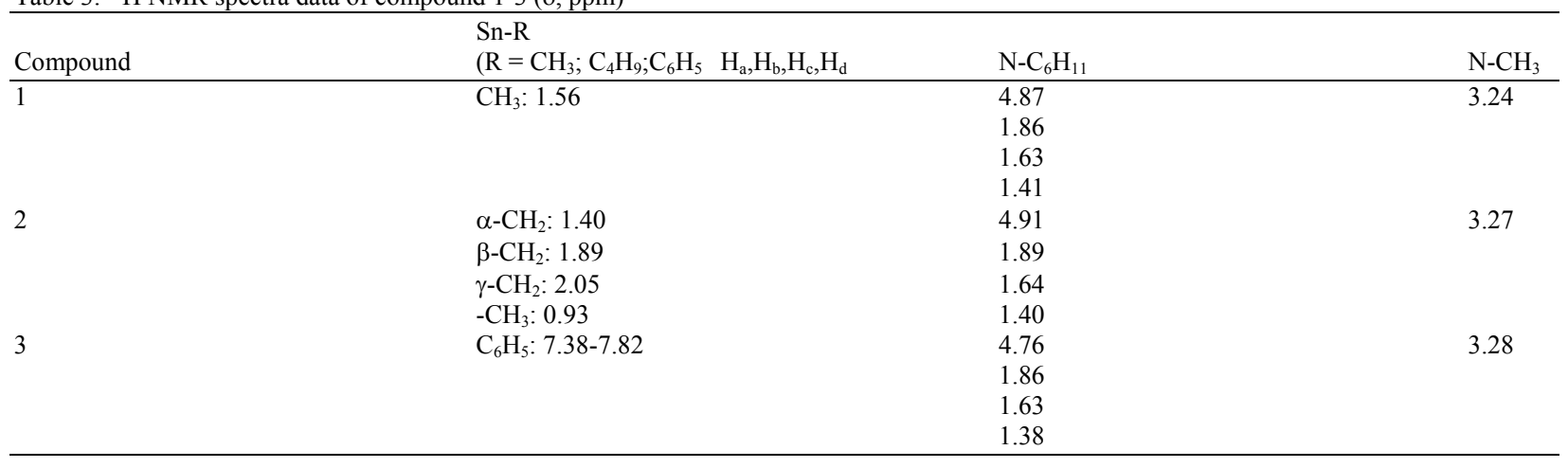

Table 4: ${ }^{13} \mathrm{C}$ NMR spectra data of compound $1-3(\delta, \mathrm{ppm})$

\begin{tabular}{lllll}
\hline Compound & $\mathrm{NCSS}$ & $\mathrm{Sn}-\mathrm{R}\left(\mathrm{R}=\mathrm{CH}_{3} ; \mathrm{C}_{4} \mathrm{H}_{9} ; \mathrm{C}_{6} \mathrm{H}_{5}\right.$ & $\mathrm{N}-\mathrm{C}_{6} \mathrm{H}_{11} \mathrm{Ca} ; \mathrm{Cb} ; \mathrm{Cd} ; \mathrm{Cc}$ & $\mathrm{N}-\mathrm{CH}_{3}$ \\
\hline 1 & 198.73 & 15.35 & $63.39 ; 29.91 ; 25.44 ; 25.31$ & 32.03 \\
2 & 199.82 & $34.57 ; 28.78 ; 26.69 ; 14.06$ & $63.50 ; 30.14 ; 25.69 ; 25.57$ & \\
3 & 196.29 & $142.81 ; 136.71 ; 128.99 ; 128.44$ & $65.32 ; 30.03 ; 25.36 ; 25.27$ & 36.72 \\
\hline
\end{tabular}

Table 5: Crystallographic data and refinement parameters for compound 1

\begin{tabular}{|c|c|}
\hline & Compound 1 \\
\hline Empirical Formula & $\mathrm{C}_{18} \mathrm{H}_{34} \mathrm{~N}_{2} \mathrm{~S}_{4} \mathrm{Sn}$ \\
\hline Formula weight & 525.40 \\
\hline Crystal system & Orthorhombic \\
\hline Space group & Pnma \\
\hline Crystal size $(\mathrm{mm})$ & $0.27 \times 0.22 \times 0.16$ \\
\hline $\mathrm{a}(\AA)$ & $13.200(9)$ \\
\hline $\mathrm{b}(\AA)$ & $19.965(14)$ \\
\hline $\mathrm{c}(\AA)$ & $8.950(6)$ \\
\hline$\alpha\left(^{\circ}\right)$ & 90 \\
\hline$\beta\left(^{\circ}\right)$ & 90 \\
\hline$\gamma\left(\left(^{\circ}\right)\right.$ & 90 \\
\hline $\mathrm{V}\left(\AA^{3}\right)$ & $2358.7(3)$ \\
\hline Z & 4 \\
\hline $\mathrm{D} / \mathrm{Mgm}^{-3}$ & 1.480 \\
\hline$\mu\left(\mathrm{mm}^{-1}\right)$ & 1.442 \\
\hline $\mathrm{F}(000)$ & 1080 \\
\hline Color & Colorless \\
\hline Temperature (K) & 293(2) \\
\hline$\theta$ range $\left(^{\circ}\right)$ & $2.04-27.56$ \\
\hline Index ranges $( \pm \mathrm{h}, \pm \mathrm{k}, \pm, 1)$ & $-17 / 16,-25 / 25,-11 / 11$ \\
\hline Reflection collected/unique & $15359 / 2795$ \\
\hline & {$\left[\mathrm{R}_{\mathrm{int}}=0.0299\right]$} \\
\hline Completeness to theta $=27.53$ & $99.7 \%$ \\
\hline Max. and min. transmission & 0.8020 and 0.6968 \\
\hline Refinement method & Full-matrix least-squares on $\mathrm{F}^{2}$ \\
\hline Data/restraints/parameters & $2795 / 0 / 118$ \\
\hline Goodness-of-fit on $\mathrm{F}^{2}$ & 0.900 \\
\hline Final $R$ indices $[I>2 \sigma(I)]$ & $\begin{array}{l}\mathrm{R}_{1}=0.0338 \\
\mathrm{wR}_{2}=0.1087\end{array}$ \\
\hline $\mathrm{R}$ indices (all data) & $\mathrm{R}_{1}=0.0400$ \\
\hline & $\mathrm{wR}_{2}=0.1165$ \\
\hline Largest diff. peak and hole (e $\left.\AA^{-3}\right)$ & 0.867 and -0.321 \\
\hline
\end{tabular}

The results for IR, ${ }^{1} \mathrm{H}$ and ${ }^{13} \mathrm{C}$ NMR spectroscopy of each compound were presented in Table 2-4, whereas the data for single crystal analysis obtained from compound 1 was shown in Table 5-6. The ORTEP plot of compound 1 is also given in Fig. 2.
Out of three compounds tested for antibacterial activity, only compound 3 showed inhibitory zones against two bacterial strains (Table 7) while in vitro cytotoxicity test indicated that compound 2-3 gave cytotoxic effect when tested on human leukemic cells, HL-60 (Table 8). 
Am. J. Applied Sci., 8 (4): 310-317, 2011

Table 6: Selected bond lengths $(\AA)$ and angles $\left(^{\circ}\right)$ for compound 1

\begin{tabular}{|c|c|c|c|}
\hline \multicolumn{4}{|l|}{ Bond length $(\AA \AA)$} \\
\hline $\operatorname{Sn}(1)-C(10)$ & $2.099(5)$ & $\mathrm{S}(1)-\mathrm{C}(8)$ & $1.749(3)$ \\
\hline $\operatorname{Sn}(1)-C(9)$ & $2.116(5)$ & $\mathrm{S}(2)-\mathrm{C}(8)$ & $1.695(3)$ \\
\hline $\operatorname{Sn}(1)-S(1)$ & $2.5173(7)$ & $\mathrm{N}(1)-\mathrm{C}(8)$ & $1.325(3)$ \\
\hline $\mathrm{Sn}(1)-\mathrm{S}(1 \mathrm{~A})$ & $2.5173(7)$ & $\mathrm{N}(1)-\mathrm{C}(7)$ & $1.456(3)$ \\
\hline $\mathrm{Sn}(1)-\mathrm{S}(2)$ & $2.9785(6)$ & $\mathrm{N}(1)-\mathrm{C}(6)$ & $1.485(3)$ \\
\hline $\operatorname{Sn}(1)-S(2 A)$ & $2.9785(6)$ & & \\
\hline \multicolumn{4}{|l|}{ Bond angle $\left({ }^{\circ}\right)$} \\
\hline C(9)-Sn(1)-C(10) & $137.00(2)$ & $\mathrm{C}(10)-\mathrm{Sn}(1)-\mathrm{S}(1 \mathrm{~A})$ & $104.08(15)$ \\
\hline $\mathrm{S}(2)-\mathrm{Sn}(1)-\mathrm{S}(2 \mathrm{~A})$ & $146.35(2)$ & $\mathrm{C}(9)-\mathrm{Sn}(1)-\mathrm{S}(1)$ & $107.51(11)$ \\
\hline $\mathrm{S}(1)-\mathrm{Sn}(1)-\mathrm{S}(1 \mathrm{~A})$ & $84.46(3)$ & $\mathrm{C}(9)-\mathrm{Sn}(1)-\mathrm{S}(1 \mathrm{~A})$ & $107.51(11)$ \\
\hline$C(10)-S n(1)-S(1)$ & $104.08(15)$ & $\mathrm{C}(8)-\mathrm{S}(1)-\mathrm{Sn}(1)$ & $95.25(9)$ \\
\hline $\mathrm{N}(1)-\mathrm{C}(8)-\mathrm{S}(2)$ & $123.45(19)$ & & \\
\hline
\end{tabular}

Table 7: The diameter of inhibitory zone $(\mathrm{mm})$ of compound 1-3 at $10 \mathrm{mg} \mathrm{mL}^{-1}$ against selected bacterial strains

\begin{tabular}{|c|c|c|c|c|}
\hline \multirow[b]{2}{*}{ Microorganisms } & \multicolumn{4}{|c|}{ Diameter of inhibition zone (mM) } \\
\hline & Compound 1 & Compound 2 & Compound 3 & $\begin{array}{l}\text { Standard } \\
\text { (Streptomycin) }\end{array}$ \\
\hline Stapyhlococcus aureus & - & - & 8 & 19.0 \\
\hline Salmonella typhimurium & - & - & 10 & 15.0 \\
\hline Pseudomonas aeruginosa & - & - & - & 20.0 \\
\hline Bacillus subtilis & - & - & - & 20.0 \\
\hline
\end{tabular}

Table 8: $\mathrm{CD}_{50}$ values of the compounds $1-3$

\begin{tabular}{ll}
\hline & $\mathrm{CD}_{50}\left(\mu \mathrm{gL}^{-1}\right)$ \\
\hline 1 & $\mathrm{HL}-60$ \\
2 & Inactive \\
3 & 0.87 \\
Etoposide & 0.18 \\
\hline
\end{tabular}

\section{DISCUSSION}

The elemental analysis as shown in Table 1 revealed that compounds were in good purity and in agreement with the general formula $\mathrm{R}_{\mathrm{m}} \mathrm{Sn}\left[\mathrm{S}_{2} \mathrm{CN}\left(\mathrm{CH}_{3}\right)\left(\mathrm{C}_{6} \mathrm{H}_{11}\right)\right]_{4-\mathrm{m}}$ (where $\mathrm{m}=2, \mathrm{R}=\mathrm{CH}_{3}$, $\mathrm{C}_{2} \mathrm{H}_{5} ; \mathrm{m}=3, \mathrm{R}=\mathrm{C}_{6} \mathrm{H}_{5}$ ). All the synthesized compounds were soluble in chloroform solvent and stable in air.

The important IR peaks of the compounds determined by the infrared spectra test were shown in Table 2. The $v(\mathrm{C}-\mathrm{N})$ modes appeared in the region of thioureide band $\left(1450-1550 \mathrm{~cm}^{-1}\right)$, while $v(\mathrm{C}=\mathrm{S})$ modes appeared in the region 950-1002 $\mathrm{cm}^{-1}$ (Ajibade et al. 2011). These indicated that dithiocarbamate legends were coordinated to the tin atom through thiol sulphur. The absence of any splitting to the $v(\mathrm{C}-\mathrm{S})$ bands that appeared in the range 974-979 $\mathrm{cm}^{-1}$ indicated a bidentate nature of the chelation of the dithiocarbamate ligands (Brown et al., 1976; Nomura et al., 1987; Mamba et al. 2010). The highest $v(\mathrm{C}-\mathrm{N})$ and $v(\mathrm{C}=\mathrm{S})$ observed for compound 3 may be due to the electron donating effect of the phenyl group compared to the other groups.
The proton magnetic resonance spectra $\left({ }^{1} \mathrm{H}\right.$ NMR spectra) of the organotin(IV) methylcyclohexyldithiocarbamate compounds were recorded in $\mathrm{CDCl}_{3}$ as shown in Table 3. The results showed that signals for methylene proton bound to nitrogen atom in the compounds in the range 3.24-3.29 $\mathrm{ppm}$. The aromatic protons of the phenyl group directly attached to the Sn atom in compound 3 were observed in the range 7.38-7.82 ppm. The ${ }^{1} \mathrm{H}$ NMR spectra of compound 1 exhibited a sharp singlet at $1.56 \mathrm{ppm}$ corresponding to the protons of methyl groups attached to the Sn atom (Yin et al. 2008). However, in the case of compound 2, four sets of signals were observed. As the butyl group is attached to electropositive Sn atom via carbon nuclei, a shielding effect was experienced through the carbon chain (Gomez-Ortiz et al., 2002). The methyl protons of the butyl group were observed as a triplet at $0.93 \mathrm{ppm}$ while broad signals were observed at $2.09,1.89$ and $1.40 \mathrm{ppm}$ for the methylene protons.

The ${ }^{13} \mathrm{C}$ NMR spectrum of the organotin(IV) methylcyclohexyldithiocarbamate compounds exhibited a signal for $\mathrm{N}_{-} \mathrm{CH}_{3}$ carbon in the range 35.81-36.72 ppm while the methyl carbon which directly attached to the $\mathrm{Sn}$ atom in compound 1 was found at $15.35 \mathrm{ppm}$ (Table 4). The $\mathrm{CS}_{2}$ resonances for compound 1 and 2 were observed at 198.73 and $199.82 \mathrm{ppm}$ respectively while in the compound 3 it was shifted to up field to about 3 ppm.

Suitable crystal for X-ray analysis of compound 1 was obtained by slow evaporation of a chloroform: Ethanol mixture at room temperature for a few days. X- 
ray data collections carried out at room temperature. The details of the crystal data and refinement parameters for compound 1 were listed in Table 5 while the selected geometric parameters were listed in Table 6 . The structure was solved by direct methods using SHELXS-97 and refined by full-matrix leastsquare calculations, using the program system SHELXS-97.

Figure 2 shows ORTEP plot of the molecules in the unit cell which showed that tin atom in compound 1 was chelated with two methyl groups and two methylcyclohexyldithiocarbamate legends which formed six-coordinated compound. In compound 1, the dithiocarbamate legends were bidentically chelated to the tin atom with one longer $[\operatorname{Sn}(1)-\mathrm{S}(2)=2.9785(6) \AA]$ and one shorter $[\operatorname{Sn}(1)-\mathrm{S}(1)=2.5169(7) \AA] \mathrm{Sn}-\mathrm{S}$ bond respectively. These values were closed to those observed earlier in $\mathrm{Me}_{2} \mathrm{Sn}\left[\mathrm{S}_{2} \mathrm{CN}\left(\mathrm{CH}_{2} \mathrm{CH}_{2} \mathrm{CH}_{2} \mathrm{CH}_{2} \mathrm{CH}_{2}\right)_{2}\right]_{2}$ (Sharma et al., 199). The long Sn-S distances were significantly less than the sum of the van der Waal's radii (4.0 $\AA$ ) (Sharma et al., 1996). Compound 1 had a crystallographic mirror plane, coinciding with the C9/Sn1/C10 plane. The $\mathrm{N}-\mathrm{C}$ bond distances in this compound $(\mathrm{N}(1)-\mathrm{C}(7)=1.456(3) \AA ; \mathrm{N}(1)-\mathrm{C}(6)=1.485$ (3) $\AA$ ) were manifestation due to the presence of a partial double bond. The IR spectrum of the above compound showed a $v(\mathrm{C}-\mathrm{N})$ value of $1475 \mathrm{~cm}^{-1}$, which lies between the single and double bond values, indicating contribution of the thioureide form to the dithiocarbamate. In this compound, the $\mathrm{N}(1)-\mathrm{C}(8)=$ $\mathrm{S}(2)$ angle $\left(123.45(19)^{\circ}\right)$ was found as expected due to the mutual repulsion between the double bond and adjacent electronegative atom. The central $\mathrm{Sn} 1$ atom is surrounded axially by $\mathrm{C} 9$ and $\mathrm{C} 10$ atoms and equatorially by S1, S2, S1A and S2A. The angle of axial $\mathrm{C}(9)-\mathrm{Sn}(1)-\mathrm{C}(10)$ is $137.00(2)^{\circ}$, deviating from $180^{\circ}$, which showed that this compound has a distorted octahedron geometry.

The antibacterial activity of the synthesized compounds solution in dimethylsulfoxide (DMSO) was tested against gram positive and gram negative bacteria consisting of Staphylococcus aureus, Salmonella typhimurium, Pseudomonas aeruginosa and Bacillus subtilis. The activity of the compounds was evaluated by measuring the diameter of the inhibition zone around the respective wells. The activity was then compared with the standard drug (Streptomycin). The results as been presented in Table 7 revealed that only compound 3 had antibacterial activity but its activity was lower than the standard drug used. The presence of phenyl groups in compound 3 bonded to tin atom is responsible for the toxicity.

The results for in vitro cytotoxicity test of compounds 1-3 were given in Table 8. Following the suggestion, $\mathrm{CD}_{50}$ values of more than $10 \mu \mathrm{g} \mathrm{mL}^{-1}$ are considered as indicative of weak cytotoxic activities while compounds with $\mathrm{CD}_{50}$ values of less than $5.0 \mu \mathrm{g}$ $\mathrm{mL}^{-1}$ are considered to be very active. Those having intermediate values between 5.0-10.00 $\mu \mathrm{g} \mathrm{mL}$ are classified as moderately active. Table 8 clearly showed that compounds 2-3 were found to be very active against human leukemic promyelocyte HL-60 cells with $\mathrm{CD}_{50}$ values of 0.87 and $0.18 \mu \mathrm{g} \mathrm{mL}^{-1}$ respectively. As compared to compound 2, compound 3 was found to be much more active to posses cytotoxicity at lower dose. This was supported by previous study tested on HepG2 cells which showed those complex derived from triphenyltin(IV) is more active than diorganotin(IV) derivatives (Win et al. 2010). Other research tested for in vitro cytotoxicity by using organotin(IV) also share the same results (Xanthopoulou et al., 2008, Hadjikakou and Hadjiliadis 2009).It has been suggested that these behaviors are exhibited due to the interaction of organotin compounds with DNA at the level of phosphate group, which may be followed by the interchelation of the legend into DNA (Casini et al., 2001).

\section{CONCLUSION}

On the basis of elemental analysis, spectral (IR, ${ }^{1} \mathrm{H}$ NMR and ${ }^{13} \mathrm{C}$ NMR) data supported by crystallographic data approved that dithiocarbamate anions have chelated to the tin atom to form the neutral compounds. The crystallographic information obtained for dimethyltin (IV) methylcyclohexyldithiocarbamate compound showed that the dithiocarbamate ligand formed bidentate chelation respectively with nonequivalent Sn-S bond distances. The screening results indicate that not all compounds exhibited antibacterial activity. It can be noted that compound with phenyl groups showed inhibitory effect on selected types of bacteria. Cytotoxicity assays of the compounds confirm the potential of these compounds, which can be used for clinical trials after further research.

\section{ACKNOWLEDGEMENT}

We would like to thank the Higher Education Ministry for the financial support (Grant: UKM-NN-06FRGS0007-2007) and the University Kebangsaan Malaysia for supporting this study. We would also like to thank Prof Bohari M. Yamin from School of Chemical Sciences and Food Technology, Universiti Kebangsaan Malaysia for X-ray single crystal 
determination. Technical support from laboratory assistants of Faculty Science and Technology, University Kebangsaan Malaysia is gratefully acknowledged.

\section{REFERENCES}

Affan, M.A., S.W. Foo, I. Jusoh, S. Hanapi and E.R.T. Tiekink, 2009. Synthesis, characterization and biological studies of organotin(IV) complexes with hydrazone ligand. Inorganica Chim. Acta, 362: 5031-5037. DOI:10.1016/j.ica.2009.08.010

Ajibade, P.A., D.C. Onwudiwe and M.J. Moloto, 2011. Synthesis of hexadecylamine capped nanoparticles using group 12 complexes of $\mathrm{N}$-alkyl- $\mathrm{N}$-phenyl dithiocarbamate as single-source precursors. Polyhedron, 30: 246-252. $\quad$ DOI: 10.1016/j.poly.2010.10.023

Alama, A., B. Tasso, F. Novelli and F. Sparatore, 2009. Organometallic compounds in oncology: Implications of novel organotins as antitumor agents. Drug Discovery Today, 14: 500-508. DOI:10.1016/j.drudis.2009.02.002

Ali, M.A., M. Nazimuddin, R. Shaha, R.J. Butheer and J.C. Bryan, 1999. Synthesis and characterization of bis-chelated nickel(II) complexes of the methylpyruvate Schiff bases of Salkyldithiocarbazates and the X-ray crystal structure of the [Ni(ONSMe)2] complex. Polyhedron, 17: 3955-3961. DOI: 10.1016/S02775387(98)00189-2

Amini, M.M., A. Azadmeher, V. Alijani, H.R. Khavazi and T. Hajiaashrafi et al., 2009. Di- and triorganotin(IV) carboxylates derived from triorganotin(IV) iodide with mixed organic groups on tin: Cyclic, hexameric triorganotin(IV) carboxylates. Inorganica Chim. Acta, 362: 355-360. DOI:10.1016/j.ica.2008.04.009

Andrews, J.M., 2001. BSAC standardized disc susceptibility testing method. J. Antimicrobial Chemotherapy, 48: 48-57. PMID: 11420336 http://www.ncbi.nlm.nih.gov/pubmed/11420336

Brown, D.A., W.K. Glass and M.A. Burke, 1976. The general use of I.R. spectral criteria in discussions of the bonding and structure of metal dithiocarbamates. Spectrochimica Acta Part A: Molecular Spectroscopy, 32: 137-143. DOI: 10.1016/0584-8539(76)80059-1

Casini, A., L. Messori, P. Orioli, M. Gielen and M. Kemmer et al., 2001. Interactions of two cytotoxic organotin(IV) compounds with calf thymus DNA. J. Inorg. Biochem., 85: 297-300. DOI: 10.1016/S0162-0134(01)00215-X
Gleeson, B., J. Claffey, D. Ertler, M. Hogan and H. Muller-Bunz et al., 2008. Novel organotin antibacterial and anticancer drugs. Polyhedron, 27: 3619-3624. DOI: 10.1016/j.poly.2008.09.009

Gomez-Ortiz, L.A., R. Cea-Olivares, V. GarcíaMontalvo and S. Hernández-Ortega, 2002. Dimeric dithiocarbamates of stannolane. An example of the presence of secondary bonds in the formation of an inorganic ring. Molecular and crystal structure of 2-" ${ }^{\mathrm{n}}$ butyl-2-(dimethyldithiocarbamate)-1,3,2-

oxathiastannolane and 2- ${ }^{\mathrm{n}}$ butyl-2(piperidyldithiocarbamate)-1,3,2-

oxathiastannolane. J. Organomet. Chem., 654: 5155. DOI: $10.1016 / \mathrm{S} 0022-328 \mathrm{X}(02) 01373-6$

Hadjikakou, S.K. and N. Hadjiliadis, 2009. Antiproliferative and anti-tumor activity of organotin compounds. Coordination Chemistry Reviews. 253: 235-249. DOI: 10.1016/j.ccr.2007.12.026

Kang, W., X. Wu and J. Huang, 2009. Synthesis, crystal structure and biological activities of four novel tetranuclear di-organotin(IV) carboxylates. J. Organom. Chem., 694: 2402-2408. DOI: 10.1016/j.jorganchem.2009.03.025

Maiti, A., A.K. Guha and S. Ghosh, 1988. Ligational behavior of two biologically active N-S donors toward oxovanadium(IV) ion and potentiation of their antibacterial activities by chelation to. J. Inorg. Biochem., 33: 57-65. DOI: 10.1016/01620134(88)80034-5

Mamba, S.M., A.K. Mishra, B.B. Mamba, P.B. Njobeh and M.F. Dutton et al., 2010. Spectral, thermal and in vitro antimicrobial studies of cyclohexylamine$\mathrm{N}$-dithiocarbamate transition metal complexes. Spectrochimica Acta Part A: Mol. Biomol. Spectroscopy, 77: 579-587. DOI: 10.1016/j.saa.2010.06.002

Manav, N., N. Gandhi and N.K. Kaushik, 2000. Some tribenzyl tin(IV) complexes with thiohydrazides and thiodiamines. Synthesis, characterization and thermal studies. J. Therm. Anal. Calorom., 61: 127-134. DOI: 10.1023/A:1010116809079

Mohan, M., A. Agarwal and N.K. Jha, 1988. Synthesis, characterization, and antitumor properties of some metal complexes of 2,6-diacetylpyridine bis $\left(\mathrm{N}^{4}\right.$ azacyclic thiosemicarbazones). J. Inorg. Biochem., 34: 41-54. DOI: 10.1016/0162-0134(88)85016-5

Mosmann, T., 1983. Rapid colorimetric assay for cellular growth and survival: Application to proliferation and cytotoxicity assays. J. Immunol. Methods, 65: 55-63. PMID: 6606682 
Nomura, R., A. Takabe and H. Matsuda, 1987. Facile synthesis of antimony dithiocarbamate complexes. Polyhedron, 6: 411-416. DOI: 10.1016/S02775387(00)81000-1

Ruan, B., Y. Tian, H. Zhou, J. Wu and R. Hu et al., 2011. Synthesis, characterization and in vitro antitumor activity of three organotin(IV) complexes with carbazole ligand. Inorganica Chim. Acta, 365: 302-308. 10.1016/j.ica.2010.09.024

Sharma, J., Y. Singh, R. Bohra and A.K. Rai, 1996. Synthesis and spectral studies of diorganotin heterocyclic dithiocarbamate complexes: The crystal structure

of $\left(\mathrm{CH}_{3}\right)_{2} \mathrm{Sn}\left[\mathrm{S}_{2} \mathrm{CNCH}_{2} \mathrm{CH}_{2} \mathrm{CH}_{2} \mathrm{CH}_{2} \mathrm{CH}_{2}\right]_{2}$. Polyhedron, 15: 1097-1102. DOI: 10.1016/02775387(95)00341-X

Singh, N.K., A. Srivastava, A. Sodhi and P. Ranjan, 2000. In vitro and in vivo antitumour studies of a new thiosemicarbazide derivative and its complexes with 3d-metal ions. Transit. Metal Chem., 25 : 133-140. DOI: 10.1023/A: 1007081218000

Singh, R. And N.K. Kaushik, 2008. Spectral and thermal studies with anti-fungal aspects of some organotin(IV) complexes with nitrogen and sulphur donor ligands derived from 2-phenylethylamine. Spectrochimica Acta Part A: Mol. Biomol. Spectroscopy, 71: 669-675. DOI: 10.1016/j.saa.2008.01.015

Thirumaran, S., V. Venkatachalam, A. Manohar, K. Ramalingam and G. Bocelli et al., 1998. Synthesis and characterization of bis(N-Methyl-N-ethanoldithiocarbamato) $\mathrm{M}(\mathrm{II})(\mathrm{M}=\mathrm{Zn}, \mathrm{Cd}, \mathrm{Hg})$ and Bis(N,N-(iminodiethylene)bisphthalimidedithiocarbamato)M(II) ( $\mathrm{M}=\mathrm{Zn}, \mathrm{Cd}$, $\mathrm{Hg}$ ) complexes. Single crystal X-ray structure of bis(di(2-hydroxyethyl)-dithiocarbamato)zinc(II). J. Coord. Chem., 44: 281-288. DOI: 10.1080/00958979808023080
Win, Y.F., S.G. Teoh, T.S. Tengku-Muhammad, Y. Sivasothy and S.T. Ha, 2010. Synthesis and characterization of Organotin(IV) complexes derived of 3-(Dimethylamino)benzoic acid: Cytotoxic assay on human liver carcinoma cells (HepG2). Am. J. Applied Sci., 7: 301-308. DOI: 10.3844/ajassp.2010.301.308

Wu, X., W. Kang, D. Zhu, C. Zhu and S. Liu, 2009. Synthesis, crystal structure and biological activities of two novel organotin(IV) complexes constructed from 12-(4-methylbenzoyl)-9,10-dihydro-9,10ethanoanthracene- 11-carboxylic acid. J. Organometallic Chem., 694: 2981-2986. DOI:10.1016/j.jorganchem.2009.04.040

Xanthopoulou, M.N., S.K. Hadjikakao, N. Hadjiliadis, E.R. Milaeva and J.A. Gracheva et al., 2008. Biological studies of new organotin(IV) complexes of thioamide ligands. European J. Med. Chem.. 43: 327-335. DOI: 10.1016/j.ejmech.2007.03.028

Yin, H.D., J. Zhai, Y.Y. Sun and D.Q. Wang, 2007. Synthesis, characterizations and crystal structures of new antimony (III) complexes with dithiocarbamate ligands. Polyhedron, 27: 663-670. DOI: 10.1016/j.poly.2007.10.019 